\title{
DISSERTAÇÕES
}

\section{Cooperativas sociais no Brasil: debates e práticas na tecitura de um campo em construção}

Rita de Cássia Andrade Martins

\author{
Curso: Mestrado em Sociologia \\ Data da defesa: 2 de julho de 2009 \\ Orientadora: Prof ${ }^{\mathrm{a}} \mathrm{Dr}^{\mathrm{a}}$ Christiane Girard Ferreira Nunes
}

\section{Resumo}

No panorama internacional, a noção de cooperativa social está diretamente relacionada ao conceito de empresa social. Esse tipo de organização é definido como empreendimento que visa à assistência social e à inclusão laboral de pessoas em situação de desvantagem. As primeiras experiências brasileiras dessa natureza surgiram a partir do movimento antimanicomial sob forte influência do modelo italiano de empresa social, onde prepondera a forma de organização do trabalho nos moldes cooperativistas. Este estudo busca consolidar os debates e práticas em torno das cooperativas sociais no Brasil com o objetivo de delinear o cenário composto por esses empreendimentos no país. Três questões centrais nortearam o trabalho: Como se caracterizam as cooperativas sociais no Brasil? Quais os principais atores sociais envolvidos nesses empreendimentos? Como tem sido construída a articulação entre esses atores na constituição deste campo?

Para desenvolver o processo de investigação foram utilizadas três fontes de informação: 1) visita de campo a cooperativas sociais brasileiras e italianas; 2) pesquisa a acervos documentais sobre as 
práticas da psiquiatria no Brasil; e, 3) análise do banco de dados do Sistema de Informação em Economia Solidária (Sies/Senaes/ MTE).

A pesquisa permitiu a elaboração de um quadro preliminar das cooperativas sociais brasileiras, o que possibilitou traçar as principais características desses empreendimentos e os seus desafios tanto no plano das práticas quanto no plano teórico. Além disso, este estudo oferece subsídios para uma melhor compreensão das especificidades do cooperativismo social, que vem se constituindo no cenário nacional a partir da interface com o campo da Economia Solidária.

Palavras-chave: cooperativas sociais; saúde mental; economia solidária; trabalho; inclusão social. 